\title{
The family in face of the elderly's reality of living alone
}

\author{
A família frente a realidade do idoso de morar sozinho \\ La familia delante la realidad del anciano que vive solo
}

\section{Marcelo Geovane Perseguino', Ana Lucia de Moraes Horta', Circéa Amália Ribeiro"}

' Universidade Federal de São Paulo, Paulista Nursing School, Postgraduate Program in Nursing. São Paulo, Brazil.

"Universidade Federal de São Paulo, Paulista Nursing School, Department of Pediatric Nursing. São Paulo, Brazil.

How to cite this article:

Perseguino MG, Horta ALM, Ribeiro CA. The family in face of the elderly's reality of living alone.

Rev Bras Enferm [Internet]. 2017;70(2):235-41. DOI: http://dx.doi.org/10.1590/0034-7167-2016-0398

Submission: 08-03-2016

Approval: 08-30-2016

\section{ABSTRACT}

Objective: to understand the family dynamics in face of the reality of the elderly living alone. Method: study of qualitative approach with theoretical reference of symbolic interactionism that involved interviews with families. Data were analyzed by thematic analysis. Results: six families participated in the study. The discourse analysis originated the following categories: The family respecting their decision making; The family organizing itself to the process of living alone after the age of 80 years; The family experiencing the freedom of living alone. Conclusion: in this study, it was possible to identify the facilitation of the possibility of living alone with preparation and agreements between the family during the family life cycle, leading to the feeling of freedom and quality of life of all members. Nursing, as a science responsible for elaborating care strategies, should work together with families to assist in the planning of care plans based on the individual social reality of the family.

Descriptors: Elderly; Housing; Family Nursing; Family Relationships; Geriatric Nursing.

RESUMO

Objetivo: compreender a dinâmica familiar frente a realidade do idoso de morar sozinho. Método: estudo de abordagem qualitativa, com referencial teórico do Interacionismo Simbólico e que envolveu entrevistas com famílias. Os dados foram analisados por análise temática. Resultados: seis famílias participaram do estudo. A análise de discurso originou as seguintes categorias: A família se organizando ao processo de morar sozinho após os 80 anos; A família respeitando as suas tomadas de decisão; A família vivenciando a liberdade do morar sozinho. Conclusão: neste estudo foi possível identificar que a possibilidade de morar sozinho é facilitada pelo preparo e acordos da família durante o ciclo vital familiar, levando à sensação de liberdade e qualidade de vida de todos os membros. A enfermagem, como ciência responsável pela elaboração de estratégias de cuidado, deve trabalhar junto às famílias auxiliando no planejamento de planos assistenciais baseados na realidade social familiar individual.

Descritores: Idoso; Habitação; Enfermagem Familiar; Relações Familiares; Enfermagem Geriátrica.

\section{RESUMEN}

Objetivo: comprender la dinámica de la familia frente a la realidad de los ancianos que viven solos. Método: estudio cualitativo con el marco teórico de la interacción simbólica y que incluyó entrevistas con las familias. Los datos fueron analizados mediante el análisis temático. Resultados: seis familias participaron en el estudio. El análisis del discurso ha originado las siguientes categorías: La familia respeta su toma de decisiones; La familia se organiza al proceso de vivir solo después de 80 años; La familia experimenta la libertad del vivir solo. Conclusión: en este estudio se observó que la posibilidad de vivir solo se ve facilitada por la preparación y las disposiciones de la familia en el ciclo de vida familiar, dando lugar a una sensación de libertad y la calidad de vida de todos los miembros. La enfermería, como la ciencia encargada de desarrollar estrategias de atención, debe trabajar con las familias para asistir en la planificación de los planes de atención basados en la realidad social familiar individual.

Descriptores: Anciano; Vivienda; Enfermería de la Familia; Relaciones Familiares; Enfermería Geriátrica. 


\section{INTRODUCTION}

The number of older people in the world rose rapidly in the $20^{\text {th }}$ century. This increase is dominated by less developed regions, where improved living conditions lead to lower population mortality, increasing longevity. In 1950, the elderly population in developing countries was 108 million, and in 2013 this number became five times higher, with 554 million elderly people ${ }^{(1)}$.

Brazil is in the group of developing countries, and the elderly population is also growing rapidly. The number of elderly people reaches $10.8 \%$ of the Brazilian population, about 20,590,599 inhabitants aged over 60 years. In 2050, it is expected that children from 0 to 14 years will represent $13.15 \%$ of the total population, while the elderly population will reach $22.71 \%$, which characterizes the inversion of the population pyramid ${ }^{(2-4)}$.

In Latin America and the Caribbean, the number of elderly people showed a very similar behavior, rising from $6.5 \%$ of the population in 1950 to $11.1 \%$ in 2000, and a projection of $18.1 \%$ in $2050^{(1)}$. In Brazil, elderly people correspond to $1.7 \%$ of the population, a significant increase when compared to 1950 , when they corresponded to $0.4 \%(3,233,749$ inhabitants) of the population ${ }^{(4)}$.

Brazil has shown a rapid increase in the number of elderly people in single-person households. In 1992, this population was $7.3 \%$, rising to $8.6 \%$ in 1999 and $9.2 \%$ in $2001^{(4)}$. Currently, $13 \%$ of the elderly population lives in single-person residences. People living in urban centers are $20 \%$ more likely to live alone compared to those living in rural areas, a fact explained by more traditional family values. However, the high cost of living in urban areas and the impossibility of leaving work to care for the elderly are important family factors that make it difficult to care for and accompany the elderly living alone ${ }^{(3-4)}$.

The growth of single-person households of elderly people brings the problem of the need for care, because the aging process results in vulnerability characterized by dependence. In Brazil, the family is the main responsible for the care of the elderly member. They have the obligation to attend the elderly's needs, but have their own socioeconomic incapacities, and those imposed by the elderly person's choice to live alone ${ }^{(5)}$.

\section{METHOD}

\section{Ethical aspects}

The study followed the ethical aspects of the Research Ethics Committee based on Resolution number 466/12, which reports on aspects of human research - National Health Council of the Ministry of Health and Declaration of the World Medical Association of Helsinki, 2013. During the study, participants were given the possibility to withdraw their consent or participation without any loss.

\section{Type of study and theoretical methodological reference}

The objective of this work was to understand the family dynamics facing the reality of the elderly living alone. It is a study with qualitative approach and theoretical reference of symbolic interactionism. This theoretical perspective enables the understanding of how individuals interpret objects and other people with whom they interact, and how this process of interpretation leads the individual behavior in specific situations. We used the semi-structured interview for data collection.

\section{Methodological procedures}

The research was performed in the residence of the elderly. For the choice of participants was conducted a pre-interview with the elderly who met the following inclusion criteria: age greater than 80 years, living alone for more than two years, living in the city of São Paulo, and having relatives living in the same city or nearby. The exclusion criterion was the presence of medical diagnoses that compromised the autonomy and independence of the elderly participant, and family unavailability at the time of the interview.

Initially, eight elderly people were contacted for a pre-interview. On this occasion the inclusion and exclusion criteria were identified, and a genogram was made to identify the members of the current family for the elderly person. After the pre-interview, were chosen six families that met the criteria. The number of members in each family ranged from five to eight people. It was considered as family a group with relationships between people who share meanings of their existential experiences ${ }^{(6)}$. Thus, the blood family and extended family were considered according to the criteria provided by the elderly person.

Older individuals aged over 80 years were listed because of their characteristics that increase the risk of vulnerability and fragility according to the PAHO criteria ${ }^{(7)}$. The criterion of two years in a single-person residence is justified by the fact that after this period, the family and the elderly person are already adapted to the process of living alone.

After the pre-interview, the first author clarified about the need to record the audio interview, and two interviews were scheduled with the elderly person and the people identified by her in the genogram as current family.

Family members were contacted by phone by the first author and the elderly, and informed about the ethical precepts. Before the interview, the informed consent form was read and signed.

The first author conducted semi-structured interviews with the elderly person and family together with duration of approximately 90 minutes each. The following main question was used as objective: How do you live with the reality of having an elderly person in the family who lives alone?

Data were collected through audio recordings, participatory observation (body language, living conditions, voice tones and other nonverbal expressions) and through the genogram.

Participants were identified by ordinal numbers as Family 1, Family 2, Family 3 and Family 4. The family members were identified by means of kinship in relation to the elderly person, plus their family number, as Child 1, Daughter-in-law 1, Sister 1, Grandson 1.

Data were duly transcribed by the author, who is a nurse and family therapist, and analyzed through content analysis based on thematic or category analysis, which consists in discovering the 'meaning nuclei' that form the messages ${ }^{(8)}$.

The following stages of analysis were followed by the first author and reviewed by the other authors: 1) pre-analysis organization phase, with floating reading procedures and 
elaboration of indicators that supported the interpretation; 2) exploitation of the material - data were encoded from the recording units; 3 ) treatment of results and interpretation categorization was made by classification of the elements according to their similarities and by differentiation, with later regrouping based on common characteristics.

Thus, categories were created based on data from the literature review to emphasize the regularity of appearance of themes, and open space to new categories during the analysis.

During the phases of pre-analysis and material exploration, we used the systemic model as theoretical basis for data organization. In this model, the family is seen as a system of relationships organized according to certain common goals that would not be reached separately by the different members ${ }^{(9)}$. The family is considered as a unique system that cannot be described by the sum of its parts, hence the group responses and not the individual responses were considered.

In order to establish the criteria of credibility, transferability, confirmability and reliability, was used the triangulation method with multiple methods, collection techniques or data sources, in an attempt to partially overcome the deficiencies that could result from the investigation or the method. For the credibility assessment, were chosen families of different social and cultural conditions. The interviews were conducted by the first researcher, who was always alert to clarify the doubts of the interviewees and deepen the pertinent subjects to the study objective. Data were analyzed by the other researchers ${ }^{(10)}$.

The transferability was reached through data saturation, identified by the repetition of themes in the material collected in different interviews. This material was analyzed by the different researchers to reduce the influence of the first researcher. To guarantee data reliability, the other researchers used a detailed textual description of the data collection and revision method in each phase of the categorical construction process. This was mandatory to proceed for the next phase of analysis. This way, the phases of initial detailed encoding, creation of meaning units, subcategories and categories were analyzed by each researcher before the beginning of the next phase ${ }^{(11)}$.

\section{RESULTS}

The present study included six families with members chosen by the elderly person in the pre-interview. They were identified in the genogram and considered by the elderly as her current family. The other family members in the genogram were not considered as family by the elderly because of personal reasons such as distance, abandonment or neglect with direct care of the elderly person.

The following categories emerged from data analysis:

\section{Category 1: The family respecting their decision making}

Living alone is an option of the elderly person and the family. It depends on the elderly person's ability to maintain independence and autonomy. The family recognizes these abilities and needs as important factors to sustain the option to live alone.

Families recognize the elderly person's abilities of decision making and performance of daily life activities. Even though they need help in many activities, the family respects the elderly person's need and willingness to continue to live alone. Reports of age-related physical limitations and sequelae of chronic diseases were common, although these did not seem to be limitations in the family adaptation process.

\section{Category 2: The family organizing itself to the process of} living alone after the age of $\mathbf{8 0}$ years

Even before the elderly person started to live alone, families were already prepared for the possibility of the elderly maintaining an independent life. The proximity of the children's and the elderly's residence, owning a property or having a family member willing to participate in this transition process were strategies used by the interviewed families.

The presence of the caregiver child is a constant fact in the families interviewed. The help with activities includes travelling to more distant locations, such as trips and doctor visits, bureaucratic and financial issues, and providing a sense of security for the elderly.

The process of living alone causes some children to get closer to the elderly and others to withdraw themselves or wait for requests for their presence. There is no agreement among family members regarding who will be responsible for helping the elderly person living alone. Hence it seems to be a spontaneous process of the family. Family caregivers assume direct care but maintain communication with other family members, sharing the responsibility for decisions.

Having an elderly member living alone generates concern in the family about the risk of violence, falls and the need for help in activities of daily living. Although the elderly people recognize the family's willingness to have them living with the children, they prefer to remain alone to maintain their autonomy.

\section{Category 3: The family experiencing the freedom of living} alone.

The interviewed elderly described the family as a reason for joy, companionship and safety. The security of having someone close and always willing to meet the needs when called was described as relevant by the interviewees. Having the family close also provides the possibility of maintaining autonomy.

For the interviewed elderly, living alone provides the freedom of decision making. The family respects the decision of the elderly and assists in the process of living alone. The speech of not 'bothering' and disrupting the family is seen as a strategy to maintain freedom for decision making far from the influence of children.

\section{DISCUSSION}

In this study, the meaning attributed to the family by the elderly follows the precepts of symbolic interactionism constructed through human interactions. The meaning comes from social interaction. Thus, the meaning given to the family by elderly people arises through their family relationship with the people they interact with, i.e., the blood bonds bring the meaning of familiar. However, the greater closeness and quality in relationships help to build the meaning of family ${ }^{(12)}$. 
The family is characterized by the fundamental aspects of affection, commitment, presence, and assistance on survival (safety, nourishment and maintenance of home). There is also the affective, cognitive and social development, and feelings of being cared for, loved and accepted, which may justify the differentiation between family members and family by the elderly. Family systems are not determined by their structure or social role, but by their relational dynamics organized around shared meanings, where the problems are experienced ${ }^{(13)}$.

The ease of being able to have a residence of their own, the proximity of their children, and having a family member living with the elderly person during the process of widowhood are aspects described in the literature that facilitate the choice of living alone. The results of this study allowed the observation of this reality and another point, which was the gradual process of living alone, with the presence of a single child still living with the elderly person after the widowhood process ${ }^{(3)}$.

The presence of the caregiver child, described in the literature as the family member of closest contact with the elderly member, was identified in all interviewed families. The relationships between the care and the meaning of family are very similar for the elderly people interviewed. They identified as family only the relatives who provided concrete family support based on acts of assistance ${ }^{(14)}$.

In view of the paradigm of the need to care for its members and the introduction of women into the labor market, the family demands social changes for the preservation and recognition of care $^{(15)}$. Among these changes, are the International Labor Organization recommendations (2009), with emphasis on recognizing the work of the family caregiver and the responsibility of the state in the care. We can also mention the orientation of deconstructing women's role as caregivers and responsible for domestic work, and of men's role as ideal workers, with re-evaluation of the roles of motherhood and fatherhood ${ }^{(16)}$.

Adjustments to the new independent life after widowhood and the possibility of changing the family status in a refusal to give up on some social roles added to power in the family may be conflicting factors in the family relationship. The change in the characteristic familial function of women, from caregiver to the position of being cared for can generate changes in the Self of the elderly person ${ }^{(17)}$.

The change in family roles leads to a reflection on the I and me that constitute the Self, that is, the way I identify myself as a person in the family and how I identify the family's view of $\mathrm{me}^{(18)}$. The process of leaving the role of caregiver, and start being cared for by the children in a reversal of roles can lead to family conflicts ${ }^{(19)}$.

The resilience capacity presented by families is an important factor to maintain a good family relationship and mental health, and may interfere in the longevity of the elderly person. More resilient families can adapt better to changes presented by the life cycle, whether physical, the presence of chronic disabling diseases and mental diseases related to withdrawnness, depression and isolation ${ }^{(20-22)}$.

In all families interviewed, there was a communication movement between the main caregiver and the other family members with the objective to share the responsibility of decision making. Even those who are more distant or have minimal relationships with other relatives are informed about the health and financial conditions of the elderly family member cared by the primary caregiver.

The symbol used to describe thoughts, observations and the imagination is called language and has the purpose of expressing social reality. The communication with use of words, gestures and behaviors in the dialogues presents meanings originated in social and familiar relations constructed in the interactions that start to be considered like symbols when added to a meaning ${ }^{(13)}$.

The fears presented by the family members interviewed are consistent with the reality lived by the elderly in Brazil, with fear of violence, falls, difficult access to medical care and hospitals, and scarce leisure activities. These factors, coupled with disinformation about the aging process, prejudice and disrespect of the elderly are worrisome. In addition, investments and public resources to meet the specific needs of the elderly population are precarious, both in terms of quantity and quality of care ${ }^{(23-25)}$.

Although the elderly members have been evaluated by health professionals (medical professionals were mentioned in the interviews) as unable to remain alone given their need for care, families are resistant to comply with the recommendation and develop strategies to ensure they remain living alone. Thus, the family recognizes their need for care and impossibility of living alone, but resignify this concept with a new vision of care.

The new paradigmatic concept of intersubjectivity can be used to describe how the health professional influences family relationships within a systemic view, in which professionals interact with the family as part of the system and not as mere observers. Thus, the medical opinion alters family functioning and forces the search for adaptation to the new imposed reality, maintaining the concept of family system instability.

The social and material support of adult children is a fact expected by parents in the aging process. Although most elderly prefer to live with their children, the population of elderly living alone is growing in the world and in Brazil. The bonds of affection and the social obligation of the family to support its members are facts the elderly expect from their children, sons-in-law and friends. The support from family to improve well-being is an essential factor for healthy aging ${ }^{(26)}$.

According to Catão (2014), the construction of the meaning of aging as a productive phase of the life cycle, and that all human beings, regardless of age, have a socially active role and a space to be respected, should happen since childhood. The action to create a new social meaning for aging should aim at creating a culture based on human development. This is a continuous process, and aging is associated with construction projects, work, inclusion in citizenship, living with differences and humanization of oneself and the others ${ }^{(27)}$.

Living alone has brought to families the feeling of freedom of choices, maintenance of personal space, and decision about their own lives. In this process, the meanings created by families enabled the creation of strategies that overcome the limitations and dependencies, making the aging process a real fact, although with needs and care very similar to that in any other phase of the life cycle. 
According to Bauman (2014), freedom depends on two distinct social conditions and differentiates the free being from not being free. The same way as evil and good, the perception of being free implies the existence of a form of dependence from which it is expected to escape from. The meaning given to freedom is a result of social relations and depends on our stories. Thus, aging brings the possibility of dependence and social isolation, and of stop being recognized as part of society ${ }^{(28)}$.

The feeling of freedom is intensified when the elderly person feels part of a group, with possibility of participating in social and family lives, leisure activities, and living with active people of the same age, which reduces loneliness, leads to will to live and, consequently, improves the quality of life ${ }^{(29)}$. The participation in social groups for elderly people or community meetings favors these activities ${ }^{(30)}$.

The limitation of this study was not finding families with elderly male people living alone. This fact limits the reflection on the issue of gender, living alone and family. Expanding the discussion on the gender issue may describe new forms of family adaptation to care for older people living alone, new views and meanings of the family dynamics in this specific situation.

In face of the presented results, nursing care for family health should be clearly based on understanding the meanings and beliefs presented by the family social reality. This means breaking with preconceptions and ready formulas, and helping in the formulation of strategies based on partnership and comprehensive family care. The concept of family as a system that interacts within itself and with society, where the individual is the result of the construction and interaction of the whole with the purpose of common welfare, should be considered in the elaboration of care proposals in family health.

The systemic approach helps in the detailed evaluation of the family group and formation of partnerships with the family. Health professionals can act by proposing interventions and creating joint strategies to improve the familiar quality of life, where families also perceive the application of their own solutions to face problems within the meanings of their social reality.

During their work with families, nursing must rethink their attitudes towards traditional and biomedical care models, review concepts and address an amplified dimension of the concept of family and care. People should be understood as individual and collective beings, active participants in a society in which there is respect for their meanings, freedom of action and decision making in their lives and in the care with it.

\section{FINAL CONSIDERATIONS}

In this study, the identification of the possibility of living alone is facilitated by the family preparation during the family life cycle. This process begins after widowhood and separation of children by marriage. The families elect a member as the family caregiver for the elderly person. The process occurs spontaneously without a formal agreement between family members, followed by the distance of the other members. The family worries about the risk of violence and accidents that may occur with the elderly person living alone and recognize the need (often described by health professionals) of the elderly living with their family members. However, the family respects the elderly person's decision to live alone and creates strategies to maintain such decision.

The possibility of living alone brings the feeling of freedom for elderly people and their family members, because it guarantees their physical space with their memories and bonds with the community, their social space and recognition as integrating part of the society. The strategies of care and elaboration of health policies based on the vision of aging as an integral part of the family process, and family as complex and unstable systems are essential in this process, as well as the professional performance in a relation of intersubjectivity, and the understanding of meanings created by the family system within its social interaction.

Figure 1 - Diagram of the family in face of the elderly's reality of living alone 


\section{REFERENCES}

1. United Nations. UN. World Population Ageing 2013. United Nations Publ. 2013.

2. Moraes E. Atenção à saúde do idoso: aspectos conceituais. OPAS[Internet]. 2012 [cited 2014 Sep 24]; 1:98. Available from: http:// apsredes.org/site2012/wp-content/uploads/2012/05/Saude-do-Idoso-WEB1.pdf

3. Camargos MCS, Rodrigues RN, Machado CJ. Idoso, família e domicílio: uma revisão narrativa sobre a decisão de morar sozinho. Rev Bras Estud Popul[Internet]. 2011[cited 2014 Sep 24]; 28:217-30. Available from: http://www.scielo.br/pdf/rbepop/v28n1/ a12v28n1.pdf

4. Brasil. Intituto Brasileiro de Geografia e Estatística. Projeção da população do Brasil por sexo e idade para o período de 2000/2060: Projeção da população das unidades da federação por sexo e idade para o período de 2000/2030. IBGE: 2013.

5. Ors Montenegro A, Maciá Soler L. Social dependency in old age: poor training, pension and housing. Enferm Glob[Internet]. 2013[cited 2015 Jun 10];12(4):147-63. Available from: http://revistas.um.es/eglobal/article/view/157241

6. Ness TM, Student D, Hellzen OVE, Enmarker I. Struggling for independence: The meaning of being an oldest old man in a rural area. Interpretation of oldest old men's narrations. Int J Qual Stud Health Well-being[Internet]. 2014[cited 2016 Nov 10];9(1):1-8. Available from: http://www.ijqhw.net/index.php/qhw/article/view/23088/32352

7. Batista AS, Jacooud LB, Aquino L, El-Moor PD. Envelhecimento e Dependência: desafios para a Organização da Proteção Social Envelhecimento e Dependência. Coleção da Previd Social. 2008.

8. Câmara RH. Content analysis: from theory to practice in social research applied to organizations. Gerais Rev Interinst Psicol. 2011;6(2):179-91.

9. Östlund U, Bäckström B, Saveman B, Lindh V, Sundin K. A Family Systems Nursing Approach for Families Following a Stroke: Family Health Conversations. J Fam Nurs[Internet]. 2016[cited 2016 Nov 10];22(2)148-71. Available from: https://www.ncbi.nlm. nih.gov/pubmed/27090511

10. Rebar CR, Gersch CJ, Macnee CL, McCabe S. Understanding Nursing Research: using research in Evidence-Based Practice. 3.ed. London: Lippincott Williams \& Wilkins; 2011.

11. Valadão Jr VM. Pesquisa qualitativa com texto, imagem e som: um manual prático. Rev Adm Contemp[Internet]. 2004[cited 2015 Nov 28];8(2):243-3. Available from: http://www.scielo.br/pdf/rac/v8n2/v8n2a16.pdf

12. Carvalho VD de, Borges LDO, Rêgo DP do. Symbolic Interacionism: origins, assumptions and contributions to social psychology studies. Psicol: Ciênc Prof. 2010;30:146-61.

13. Dias MO. Um olhar sobre a família na perspetiva sistémica: o processo de comunicação no sistema familiar. Gestão e Desenvolv [Internet]. Universidade Católica Portuguesa. Departamento de Economia, Gestão e Ciências Sociais; 2011 [cited 2015 Sep 5];19. Available from: http://repositorio.ucp.pt/handle/10400.14/9176

14. Almeida L, Azevedo RC de S, Reiners AAO, Sudré MRS. Care performed by family caregivers to dependent elderly, at home, within the context of the Family Health Strategy. Texto Contexto Enferm[Internet]. 2012[cited 2015 Sep 16];21(3):543-8. Available from: http://www.scielo.br/pdf/tce/v21n3/en_v21n3a08.pdf

15. Küchemann BA. Envelhecimento populacional, cuidado e cidadania: velhos dilemas e novos desafios. Soc Estado. 2012;27(1):165-80

16. Organização Internacional do Trabalho. Trabalho e família: rumo a novas formas de conciliação com corresponsabilidade social. Brasilia: OIT/PNUD; 2009. 150 p.

17. Rodrigues RAP, Marques S, Kusumota L, Santos EB, Fhon JRDS, Fabrício-Wehbe SCC. Transition of care for the elderly after cerebrovascular accidents - from hospital to the home. Rev Latino-Am Enfermagem [Internet]. 2013[cited 2016 Nov 10];21(spe):21624. Available from: http://www.scielo.br/pdf/rlae/v21nspe/27.pdf

18. Blumer H. Symbolic interactionism: perspective e method. Univ Califórnia; 1969.

19. Cabote CJ, Bramble M, McCann D. Family Caregivers' experiences of caring for a relative with Younger Onset Dementia: a qualitative systematic review. J Fam Nurs[Internet]. 2015[cited 2016 Nov 10];21(3):443-68. Available from: http://jfn.sagepub.com/cgi/ doi/10.1177/1074840715573870

20. Bahremand M, Rai A, Alikhani M, Mohammadi S, Shahebrahimi K, Janjani P. Relationship between family functioning and mental health considering the mediating role of resiliency in type 2 diabetes mellitus patients. Glob J Health Sci[Internet]. 2014[cited 2015 Jun 10];7(3). Available from: http://www.ccsenet.org/journal/index.php/gjhs/article/view/40674

21. Petrowski K, Brähler $\mathrm{E}$, Zenger $\mathrm{M}$. The relationship of parental rearing behavior and resilience as well as psychological symptoms in a representative sample. Health Qual Life Outcomes[Internet]. 2014[cited 2016 Nov 10];12(1):95. Available from: http://www.hqlo. com/content/12/1/95 
22. Law J, Richmond RL, Kay-Lambkin F. The contribution of personality to longevity: Findings from the Australian Centenarian Study. Arch Gerontol Geriatr[Internet]. 2014[cited 2016 Nov 10];59(3):528-35. Available from: http://linkinghub.elsevier.com/retrieve/ $\mathrm{pii} / \mathrm{S} 0167494314001009$

23. Castro AP, Guilam MCR, Sousa ESS, Marcondes WB. Violence in old age: the issue addressed in indexed national journals. Cienc Saude Colet[Internet]. 2013[cited 2015 Sep 7];18(5):1283-92. Available from: http://www.scielo.br/pdf/csc/v18n5/13.pdf

24. Crandall CJ, LaMonte MJ, Snively BM, LeBoff MS, Cauley JA, Lewis CE et al. Physical functioning among women aged 80 years and older with previous fracture. J Gerontol A Biol Sci Med Sci[Internet]. 2016[cited 2016 Nov 10];71 (Suppl 1):S31-S41 Available from: http://biomedgerontology.oxfordjournals.org/content/71/Suppl_1/S31.long

25. Ganong LH, Coleman M, Benson JJ, Snyder-Rivas LA, Stowe JD, Porter EJ. An Intervention to Help Older Adults Maintain Independence Safely. J Fam Nurs[Internet]. 2013[cited 2016 Nov 10];19(2):146-70. Available from: http://jfn.sagepub.com/cgi/ doi/10.1177/1074840712471900

26. Chen Y-J, Chen C-Y. Living arrangement preferences of elderly people in Taiwan as affected by family resources and social participation. J Fam Hist. 2012. 37(4):381-94.

27. Catão MFFM, Grisi AFM. Life project and work as matter of exclusion/inclusion of the elderly person. Estud Psicol[Internet]. 2014 [cited 2016 Nov 10];31(2):215-23. Available from: http://www.scielo.br/pdf/estpsi/v31n2/a07v31n2.pdf

28. Bauman Z. Liberdade. São Paulo: Editora Academia Cristã; 2014. 165 p.

29. Shin SH, Sok SR. A comparison of the factors influencing life satisfaction between Korean older people living with family and living alone. Int Nurs Rev[Internet]. 2012[cited 2016 Nov 10];59(2):252-8. Available from: http://doi.wiley.com/10.1111/j.1466-7657.2011.00946.x

30. Andrade AN, Nascimento MMP, Oliveira MMD, Queiroga RM, Fonseca FLA, Lacerda SNB, et al. Elderly's perceptions of living groups: study in the city of Cajazeiras-PB. Rev Bras Geriatr Gerontol[Internet]. 2014[cited 2016 Nov 10];17(1):39-48. Available from: http://www. scielo.br/pdf/rbgg/v17n1/1809-9823-rbgg-17-01-00039.pdf 